\title{
COMPARISON OF PIXEL-BASED AND OBJECT-BASED CLASSIFICATION USING PARAMETERS AND NON-PARAMETERS APPROACH FOR THE PATTERN CONSISTENCY OF MULTI SCALE LANDCOVER
}

\author{
E. Juniati ${ }^{\mathrm{a} *}$, E. N. Arrofiqoh ${ }^{\mathrm{a}}$ \\ ${ }^{a}$ Geomatic Engineering Master's Degree Programme, Department of Geodetic Engineering, Faculty Engineering, Gadjah Mada \\ University, 55281 Yogyakarta, Indonesia - eli.juniati@big.go.id; erlyna.nour@gmail.com
}

\section{Commission III, WG III/6}

KEY WORDS: Image Classification, Pixel-Based, Object-Based, Pattern consistency, Multi-scale, Multi-source

\begin{abstract}
:
Information extraction from remote sensing data especially land cover can be obtained by digital classification. In practical some people are more comfortable using visual interpretation to retrieve land cover information. However, it is highly influenced by subjectivity and knowledge of interpreter, also takes time in the process. Digital classification can be done in several ways, depend on the defined mapping approach and assumptions on data distribution. The study compared several classifiers method for some data type at the same location. The data used Landsat 8 satellite imagery, SPOT 6 and Orthophotos. In practical, the data used to produce land cover map in 1:50,000 map scale for Landsat, 1:25,000 map scale for SPOT and 1:5,000 map scale for Orthophotos, but using visual interpretation to retrieve information. Maximum likelihood Classifiers (MLC) which use pixel-based and parameters approach applied to such data, and also Artificial Neural Network classifiers which use pixel-based and non-parameters approach applied too. Moreover, this study applied object-based classifiers to the data. The classification system implemented is land cover classification on Indonesia topographic map. The classification applied to data source, which is expected to recognize the pattern and to assess consistency of the land cover map produced by each data. Furthermore, the study analyse benefits and limitations the use of methods.
\end{abstract}

\section{INTRODUCTION}

Remotely sensed imagery and aerial photos has been utilized in mapping production. In Indonesia topographic map, land cover is one of the information layer presented. Land cover terminology relates to presentation of information about human activity which connected to specific land and the type of feature on the surface of the earth (Lillesand et al., 2004). Existing condition in Indonesia, to produce land cover information in massive production still used visual interpretation method. However, it is highly influenced by subjectivity and knowledge of interpreter, also takes time in the processing.

Land cover information extraction can be done using digital classification. (Al-Doski et al., 2013) told 'image classification had made great progress over the past decades in the following four areas: (1) producing land cover map at regional and global scale; (2) development and use of advanced classification algorithms; (3) use of multiple remote-sensing features; and (4) incorporation of ancillary data into classification procedures.' Image processing and GIS developing rapidly by the existence of object-based digital classification method and technology (Blaschke, 2010).

In recent decades, there has been a lot of research that discusses various digital classifier methods. (Jonsson, 2015) evaluate pixel-based method using Support Vector Machine (SVM) with radial basis function, Maximum Likelihood Classifier (MLC) and object-based method using segmentation and nearest neighbour classification to the SPOT 5 data. The research result that object-based classifier give the best overall accuracy in $86.2 \%$. Similar research are also done by (Bruce, 2008), (Oruc et al., 2004), (Xiaoxia et al., 2005), (Qian et al., 2007), (Gholoobi et al., 2010), (Weih and Riggan, 2010), (Avci et al., 2011), (Aguirre-Gutiérrez et al., 2012), which compared pixelbased and object-based method. The result showed that objectbased better than pixel-based method with varying percentage of accuracy. The others research comparing machine learning classifiers for World View 2 imagery. SVM and Normal Bayes (NB) better than Decision Tree (DT) and k-Nearest Neighbour (k-NN) for urban land classification (Qian et al., 2014). In the same paper, (Qian et al., 2014) tells the size of training samples is less than 125 per class can increase of classification accuracies for all four classifiers.

Topographic maps in Indonesia produced in various map scales, i.e. $1: 1,000,000 ; 1: 500,000 ; 1: 250,000 ; 1: 50,000 ; 1: 25,000$; $1: 10,000 ; 1: 5,000 ; 1: 2.500$ and $1: 1,000$. At all map scales the information about land cover should be shown on the maps. The motivation of this research is trying to quantify the use of digital classification methods, and also assess spatial consistency of land cover information resulting from the data according to existing classification standard. This research compared performance pixel-based method and object-based method, and also trying to prove the previous researches. In pixel-based method used MLC which use pixel-based and parameters approach and NN which use pixel-based and nonparameters approach. In object-based method used Multi

\footnotetext{
* Corresponding author
} 
Resolution Segmentation (MRS) and Nearest Neighbour classification. These classifiers implemented to all the data used in the research.

\section{STUDY AREA AND DATA}

The study site is in West Bandung district - West Java Province, Indonesia, which there is variety of land cover information, such as vegetation and man-made or human activity. The picture below shows the location of study area.

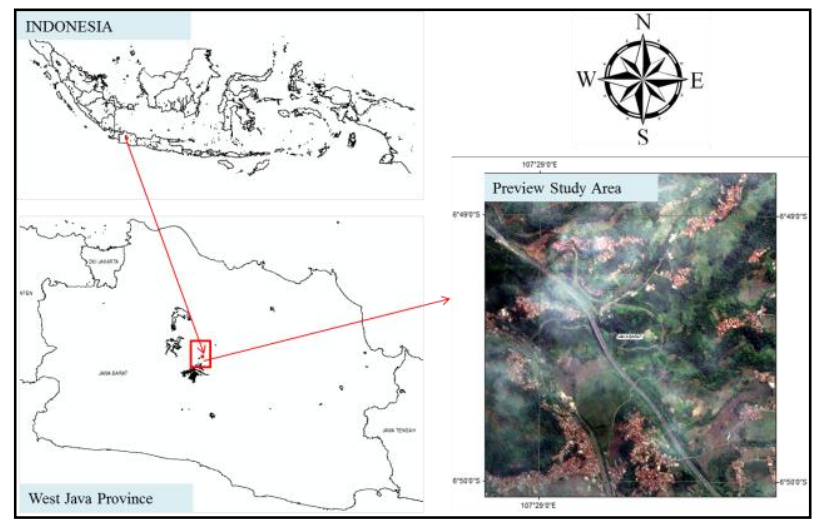

Figure 1. Location of study area

The data used in this research displayed in this table below: Table 1. Data source information:

\begin{tabular}{|c|c|c|}
\hline Data Type & Metadata & Band Used \\
\hline Landsat 8 & $\begin{array}{l}\text { Acquisition: } \\
\text { March, } 132017 \\
\text { Spatial resolution: } \\
30 \text { meter }\end{array}$ & NIR, R, G \\
\hline SPOT 6 & $\begin{array}{l}\text { Acquisition: } \\
\text { January, } 2014 \\
\text { Spatial resolution: } \\
1.5 \text { meter } \\
\text { Level-processing: } \\
\text { Standard ortho and } \\
\text { fusion with } \\
\text { panchromatic band }\end{array}$ & $\mathrm{R}, \mathrm{G}, \mathrm{B}$ \\
\hline Digital Orthophoto & $\begin{array}{l}\text { Acquisition: } \\
\text { April, } 28-\text { May, } 21 \\
2013 \\
\text { Aerial Camera: } \\
\text { Trimble ALCP65+ } \\
\text { GSD: } 15 \mathrm{~cm} \\
\text { Bundle block adjustment } \\
\text { result }<10.0 \text { micron }\end{array}$ & $\mathrm{R}, \mathrm{G}, \mathrm{B}$ \\
\hline $\begin{array}{l}\text { Indonesia } \\
\text { Topographic Map }\end{array}$ & $\begin{array}{l}\text { Production year: } \\
2013 \\
\text { Map scale: } \\
\text { 1:5.000 } \\
\text { Source data: } \\
\text { aerial photo } \\
\text { Method: } \\
\text { Visual interpretation } \\
\text { using digital softcopy } \\
\text { photogrammetry }\end{array}$ & Vector data \\
\hline
\end{tabular}

In Indonesia, Landsat satellite imagery can be utilized for 1:50,000 map scale production, SPOT6 data at standard ortho processing level has been utilized for 1:25,000 map scale and aerial photos to produce information on 1:5,000 map scale. For reasons of computer storage capacity, in this research coverage area for orthophoto divided into several region based on dominant land cover class in that region.

\section{METHODS}

'Digital classification is quantitative analysis of computer interpretation to identify pixel-based upon their numerical properties and owing to its ability for counting pixel for area estimates' (Richards and Xiuping, 2006). Following classification methods implemented to such data, and the result would be quantify statistically and spatially to assess pattern consistency.

\subsection{Pixel-Based Classification}

Pixel based classification method which will be used in this study are MLC and Neural Net classifiers. MLC is the most common supervised classification, this classifier using parametric approach which the spectral statistic data should be distributed normally, and also the decision rule in MLC to estimate from training data determined by Bayes' theorem (Richards and Xiuping, 2006). MLC use 'mean value and covariances to compute the probability of individual pixels belonging to specific class for the variation in spectral data' (Ghosh and Joshi, 2014). The methods are made not only build upon class centre, but also consider shape, size and orientation. Therefore, the statistic quality of training area or class input will affect the accuracy of classification result. Table 2 below shows threshold setting in MLC for the data source.

Table 2. Threshold setting in MLC

\begin{tabular}{lc}
\hline \multicolumn{1}{c}{ Data Type } & Threshold Value \\
\hline Landsat 8 & 1.5 \\
SPOT 6 & 1.5 \\
Orthophotos & 1.5 \\
\hline
\end{tabular}

Neural Net classifier is also supervised classification using nonparametric approach, which doesn't use influence of statistic data distributed. Neural classifiers is a machine learning algorithm, which used one model of the brain by building sets of linked processing units such as analogy neural of the brain), then using that algorithm to solve (Mather, 2004). In the same books Matter express the advantages of neural classifiers, i.e. the classifiers can accept all kind of numerical input without requiring statistical distributed; neural classifiers can recognise input as well as sampling area which have used to train; more tolerant to noise. Then the disadvantages of neural classifiers, i.e. designing problem, takes long time in processing, etc. NN commonly make good classification result, but different combination of model parameters can involve lots of effort for network training (Shao and Lunetta, 2012).

In this research, parameter setting in neural classifiers for the data source shows in table 3 below.

Table 3. Parameter setting in neural classifiers

\begin{tabular}{lccc}
\multicolumn{3}{c}{ Table 3. Parameter setting in neural classifiers } \\
\hline Parameter & Landsat 8 & SPOT 6 & $\begin{array}{c}\text { Ortho - } \\
\text { photo }\end{array}$ \\
\hline $\begin{array}{l}\text { Training threshold } \\
\text { contribution }\end{array}$ & 0.9 & 0.9 & 0.9 \\
\hline
\end{tabular}




\begin{tabular}{lccc}
\hline \multicolumn{1}{c}{ Parameter } & Landsat 8 & SPOT 6 & $\begin{array}{c}\text { Ortho - } \\
\text { photo }\end{array}$ \\
\hline $\begin{array}{l}\text { Training Rate } \\
\text { Training }\end{array}$ & 0.2 & 0.2 & 0.2 \\
$\begin{array}{l}\text { Momentum } \\
\text { Training RMS Exit }\end{array}$ & 0.9 & 0.9 & 0.9 \\
$\begin{array}{l}\text { Criteria } \\
\text { Number of Hidden }\end{array}$ & 2 & 0.1 & 0.1 \\
$\begin{array}{l}\text { Layer } \\
\text { Number of Training } \\
\text { Iterators }\end{array}$ & 1,000 & 1,000 & 100 \\
\hline
\end{tabular}

\subsection{Object-Based Classification}

Information extraction technology starts to shift from pixelbased approach to object-based approach. Object-based classification not only use pixel but also spatial measurement that characterized the shape and compactness of the region. The object-based classification implemented using eCognition software, which applied segmentation with multi resolution segmentation and supervised classification with nearest neighbour method. (Jonsson, 2015) told 'multi resolution segmentation (MRS) is a bottom up method, where segmentation starts with one pixel and, by loops, merges pixels into pairs and into larger objects.' Parameter setting in segmentation step for the data as follows:

Table 4. Segmentation parameters

\begin{tabular}{lccc}
\hline Parameters & Landsat 8 & SPOT 6 & Orthophoto \\
\hline Scale & 7 & 30 & 100 \\
parameter & & & \\
Shape factor & 0.1 & 0.15 & 0.1 \\
Compactness & 0.5 & 0.8 & 0.5 \\
\hline
\end{tabular}

Nearest Neighbor classification in eCognition is based on a fuzzy classification algorithm, where each class contains can consist sets of fuzzy expressions based on parameters. Image classification using nearest neighbour, start with select samples for each land use class which has been defined the criteria for classification and the software classifies the remainder of the image. Classification process is rather fast because object not a individual pixel anymore after segmentation.

\subsection{Land Cover Classification Schema on Indonesia Topographic Map}

In Indonesia topographic map, land cover information should be presented on map. The study will compare spatial consistency by pattern consistency of the digital classification result. The standard used for land cover classification schema on Indonesia topographic map such as Indonesia National Standard for map presentation in 1:50,000 map scale (Nasional, 2010b) and 1:25,000 map scale (Nasional, 2010a).

Table 5. Classification schema for study area

\begin{tabular}{|c|c|c|c|c|c|}
\hline \multicolumn{2}{|c|}{$\begin{array}{c}\text { 1:5,000 Topographic } \\
\text { Map }\end{array}$} & \multicolumn{2}{|c|}{$\begin{array}{c}1: 25,000 \\
\text { Topographic Map }\end{array}$} & \multicolumn{2}{|c|}{$\begin{array}{c}\text { 1:50,000 } \\
\text { Topographic Map }\end{array}$} \\
\hline Class & Shape & Class & Shape & Class & Shape \\
\hline Settlement & area & Settlement & area & Settlement & area \\
\hline $\begin{array}{l}\text { Shrubs / } \\
\text { reed }\end{array}$ & area & Shrubs & area & Shrubs & area \\
\hline $\begin{array}{l}\text { Farm/ } \\
\text { garden }\end{array}$ & area & $\begin{array}{l}\text { Farm/ } \\
\text { garden }\end{array}$ & area & $\begin{array}{l}\text { Farm/ } \\
\text { garden }\end{array}$ & area \\
\hline
\end{tabular}

\begin{tabular}{|c|c|c|c|c|c|}
\hline \multicolumn{2}{|c|}{$\begin{array}{c}\text { 1:5,000 Topographic } \\
\text { Map }\end{array}$} & \multicolumn{2}{|c|}{$\begin{array}{c}1: 25,000 \\
\text { Topographic Map }\end{array}$} & \multicolumn{2}{|c|}{$\begin{array}{c}1: 50,000 \\
\text { Topographic Map }\end{array}$} \\
\hline Class & Shape & Class & Shape & Class & Shape \\
\hline Moor & area & Moor & area & Moor & area \\
\hline $\begin{array}{l}\text { Fresh } \\
\text { Water } \\
\text { River }\end{array}$ & area & River & line & River & line \\
\hline $\begin{array}{l}\text { Paddy } \\
\text { Field }\end{array}$ & area & $\begin{array}{l}\text { Paddy } \\
\text { Field }\end{array}$ & area & $\begin{array}{l}\text { Paddy } \\
\text { Field }\end{array}$ & area \\
\hline Forest & area & Forest & area & Forest & area \\
\hline $\begin{array}{l}\text { Local } \\
\text { Road }\end{array}$ & area & Local Road & line & Local Road & line \\
\hline Highway & area & Highway & line & Highway & line \\
\hline
\end{tabular}

The colour code for each class shows on figure 2.

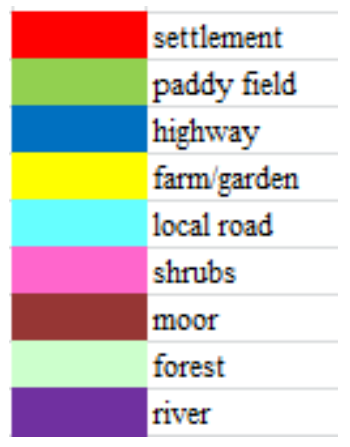

Figure 2. Class colour code

\subsection{Accuracy Assessment}

Accuracy assessment adopted for classification results is thematic accuracy. Accuracy assessment has three basic components, i.e. sampling design, response design for each training unit, estimation and analysis protocols (Stehman and Czaplewski, 1998). Error matrix or confusion matrix is common manners to explicit percentage of the map area which has been classified and compared with reference data (Story and Congalton, 1986). In this study overall accuracy and kappa value which generated from statistical computation training area to data coverage will be compared, and also tested using topographical map in 1:5,000 map scale result from visual interpretation.

\subsection{Pattern Consistency/ Consistency Assessment}

Terminology pattern consistency in this study is talks about spatial consistency from a related class in smaller scale to bigger scale, based on classification schema. Visual assessment addressed in this scope area. Examination formed with see the shape and area coverage that produced from digital classification methods. Beforehand, the data from classification result changed to vector format, and carried out the smoothing process. A complete research methodology shown in the following diagram 


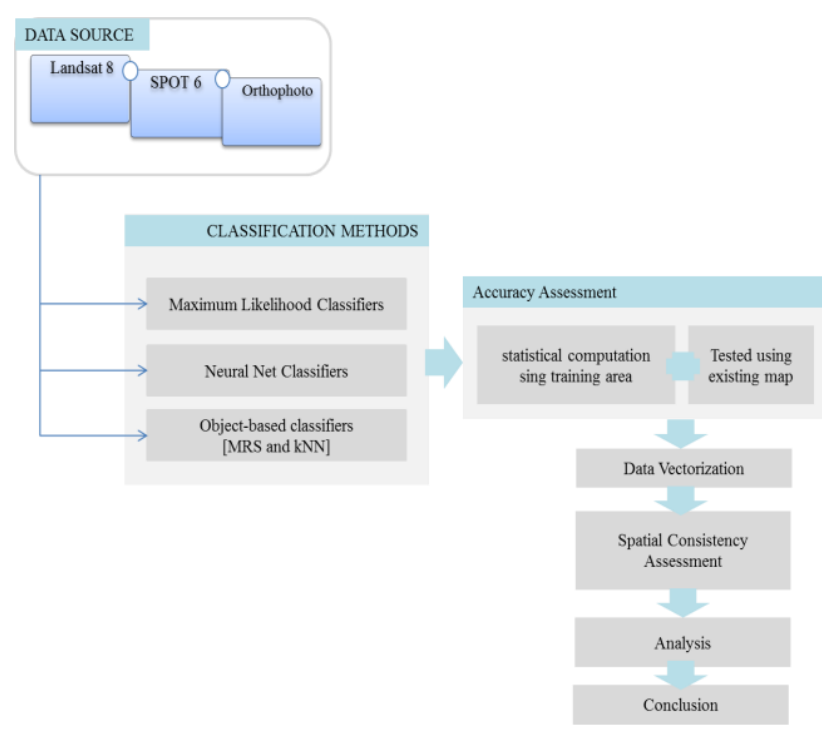

Figure 3. Research methodology

\section{RESULT AND DISCUSSION}

The classification is done with several scenarios. The first scenario is running classification to all entire study area, except for orthophoto (the result showed in table 6a), the classification running for specific area. The second scenario is running classification for specific area, where the area divided into several regions based on dominant land cover class in that region (the result showed in table $6 b$ and $6 c$ ).

\subsection{Accuracy Assessment Result}

The classification result for all the data shows in Table $6 \mathrm{a}, 6 \mathrm{~b}$ and 6c. The confusion matrix generated from statistical computation training area to data coverage will be compared.

In the first scenario, surprising result is shown from objectbased method where the overall accuracy and kappa value is 1 , then followed by Neural Net Classifiers, then MLC. The surprising result from object-based classifiers can be influenced by the dimension of area study and the number of training areas used.

Table 6a. Confusion matrix for all classification result

\begin{tabular}{|c|c|c|c|c|}
\hline \multicolumn{2}{|c|}{$\begin{array}{c}\text { Data Source / } \\
\text { Classifiers }\end{array}$} & Landsat 8 & SPOT 6 & Orthophoto \\
\hline \multirow{2}{*}{$\begin{array}{l}\text { Maximum } \\
\text { Likelihood }\end{array}$} & $\begin{array}{l}\text { Overall } \\
\text { Accuracy }\end{array}$ & $91.58 \%$ & $72.42 \%$ & $80.03 \%$ \\
\hline & Карра & 0.8945 & 0.6706 & 0.669 \\
\hline \multirow[t]{2}{*}{ Neural Net } & $\begin{array}{l}\text { Overall } \\
\text { Accuracy }\end{array}$ & $87.99 \%$ & $71.12 \%$ & $84.79 \%$ \\
\hline & Kappa & 0.8491 & 0.637 & 0.7439 \\
\hline \multirow{2}{*}{$\begin{array}{l}\text { Object- } \\
\text { based }\end{array}$} & $\begin{array}{l}\text { Overall } \\
\text { Accuracy }\end{array}$ & $100 \%$ & $100 \%$ & $100 \%$ \\
\hline & Карра & 1 & 1 & 1 \\
\hline
\end{tabular}

Table 6b. Classification result from orthophoto data, which divided into specific area study

\begin{tabular}{|c|c|c|c|c|c|c|}
\hline \multirow{2}{*}{$\begin{array}{c}\text { Dominant Class on } \\
\text { Orthophoto } \\
\text { Region }\end{array}$} & \multicolumn{2}{|c|}{ Neural Net } & \multicolumn{2}{|c|}{ MLC } & \multicolumn{2}{|c|}{ Object-based } \\
\hline & $\begin{array}{c}\text { Overall } \\
\text { Accuracy }\end{array}$ & Карра & $\begin{array}{c}\text { Overall } \\
\text { Accuracy }\end{array}$ & Карра & $\begin{array}{c}\text { Overall } \\
\text { Accuracy }\end{array}$ & Kappa \\
\hline Road & $80.11 \%$ & 0.7316 & $78.59 \%$ & 0.7191 & $100 \%$ & 1 \\
\hline Vegetation & $95.61 \%$ & 0.8335 & $85.43 \%$ & 0.609 & $100 \%$ & 1 \\
\hline Settlement & $91.63 \%$ & 0.8488 & $81.18 \%$ & 0.7084 & $100 \%$ & 1 \\
\hline Paddy Field & $71.80 \%$ & 0.5617 & $74.90 \%$ & 0.6395 & $100 \%$ & 1 \\
\hline Average Accuracy & $84.79 \%$ & 0.7439 & $80.03 \%$ & 0.6690 & $100 \%$ & 1 \\
\hline
\end{tabular}

Table 6c. Classification result from SPOT 6 data which divided into specific area study

\begin{tabular}{|l|r|r|r|r|r|r|}
\hline $\begin{array}{l}\text { Dominant Class on } \\
\text { Orthophoto Region }\end{array}$ & \multicolumn{2}{|c}{ Neural Net } & \multicolumn{2}{c}{ MLC } & \multicolumn{2}{c}{ Object-based } \\
& $\begin{array}{c}\text { Overall } \\
\text { Accuracy }\end{array}$ & Kappa & $\begin{array}{c}\text { Overall } \\
\text { Accuracy }\end{array}$ & Kappa & $\begin{array}{c}\text { Overall } \\
\text { Accuracy }\end{array}$ & Kappa \\
\hline Road & $92.03 \%$ & 0.894 & $90.88 \%$ & 0.8786 & $100 \%$ & 1 \\
\hline Vegetation & $78.67 \%$ & 0.701 & $95.25 \%$ & 0.9375 & $100 \%$ & 1 \\
\hline Settlement & $93.55 \%$ & 0.8925 & $80.66 \%$ & 0.728 & $100 \%$ & 1 \\
\hline Paddy Field & $86.49 \%$ & 0.8138 & $83.80 \%$ & 0.7901 & $100 \%$ & 1 \\
\hline Average Accuracy & $\mathbf{8 7 . 6 8 \%}$ & $\mathbf{0 . 8 2 5 3 2 5}$ & $\mathbf{8 7 . 6 5 \%}$ & $\mathbf{0 . 8 3 3 6}$ & $\mathbf{1 0 0 \%}$ & $\mathbf{1}$ \\
\hline
\end{tabular}

The second scenario, where the area study for SPOT imagery and Orthophoto divided into several regions gives relatively similar result than first scenario. Object-based classification still gives the best result, then following by NN and MLC. The Kappa value indicate 'the classification is perfect when Kappa $=1$; observed proportion correct greater than expected proportion, when Kappa $>0$; observed proportion correct similar with expected proportion, when Kappa $=0$; and observed proportion correct less than expected proportion, when Kappa $<0$ (Pontius, 2000).

The second assessment tested using topographical map in 1:5,000 map scales, picture bellow distribution of test points.

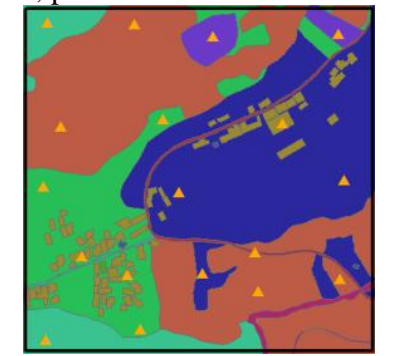

Figure 4. Test points distribution

Test point using in this assessment are 60 points which is distributed in the study area. Following table shows test point that used to compare with topographic map.

Table 7. Test Points information

\begin{tabular}{lr}
\hline \multicolumn{1}{c}{ Class } & Amount \\
\hline settlement & 3 \\
paddy field & 13 \\
highway & 3 \\
farm/garden & 21 \\
local road & 5 \\
shrubs & 4 \\
moor & 5 \\
forest & 6 \\
\hline Total & 60 \\
\hline
\end{tabular}

The accuracy result shows by following table: 
Table 8. Accuracy tested using 1:5,000 topographical maps

\begin{tabular}{l|rrr}
\hline \multicolumn{1}{c|}{ Data } & \multicolumn{1}{c}{ MLC } & Neural Net & $\begin{array}{c}\text { Object- } \\
\text { based }\end{array}$ \\
\hline Landsat 8 & $31.67 \%$ & $35.00 \%$ & $31.67 \%$ \\
SPOT 6 & $63.33 \%$ & $48.33 \%$ & $45.00 \%$ \\
Orthophotos & $64.10 \%$ & $71.79 \%$ & $61.54 \%$ \\
\hline
\end{tabular}

From the table, the accuracy result from classification process compared with visual interpretation resulting that better value achieved when used data with high spatial resolution (orthophoto). That value tend to interpreter knowledge and subjective. Visualization of classification which produced from those methods can be seen in the following table:

Table 9. Visualization classification results

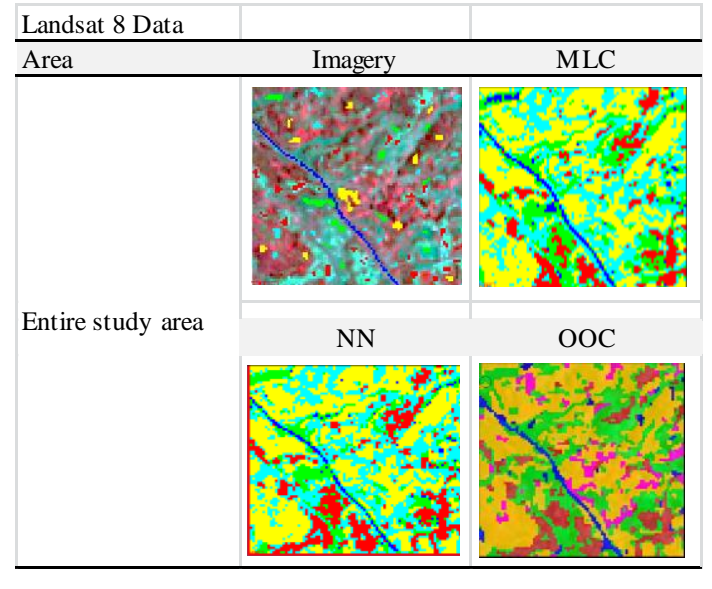
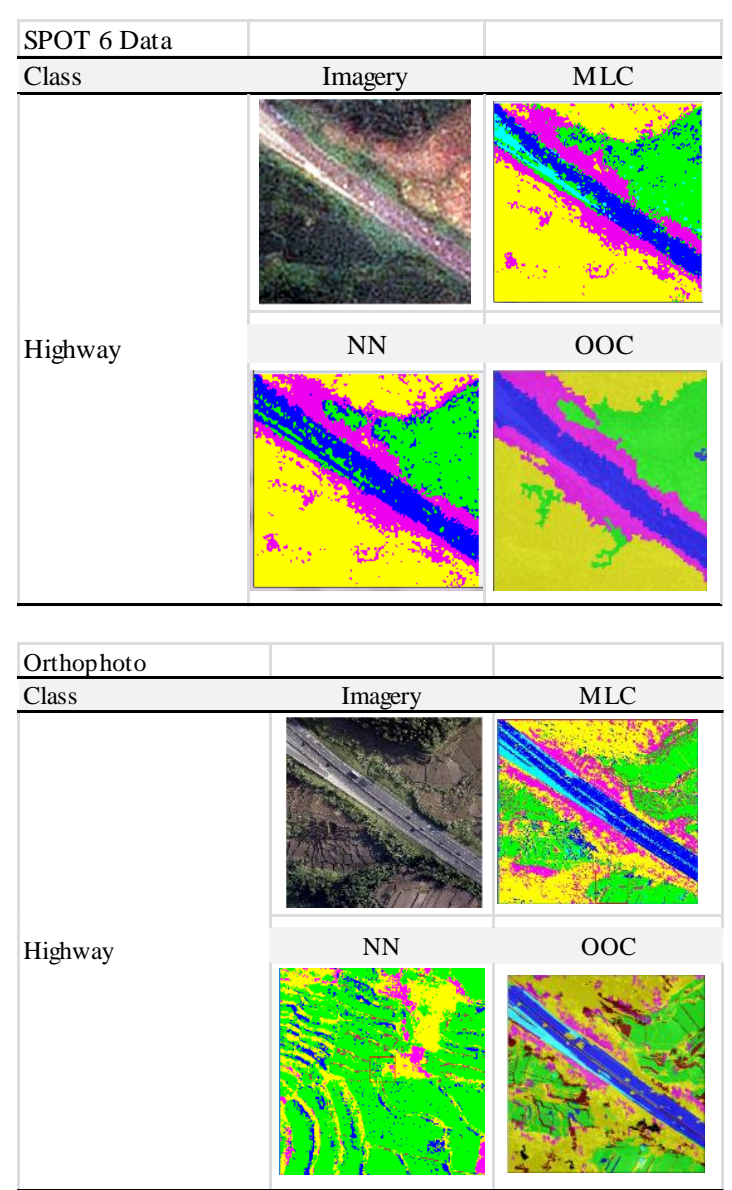

As the statistically assessment, object-based classification seems give better result than the others visually.

\subsection{Pattern Consistency Assessment}

This research undertakes such visual examination to evaluate the pattern consistency that resulting from digital classification, as seen in following figures:
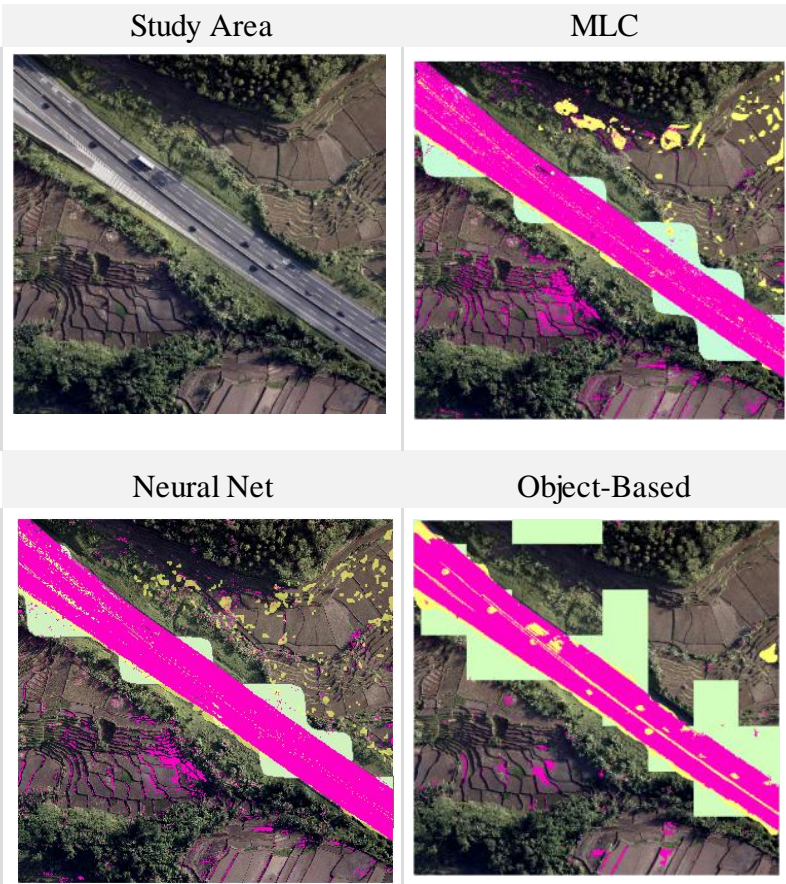

Figure 5. Pattern consistency for highway feature that retrieved from several data with several digital classification methods
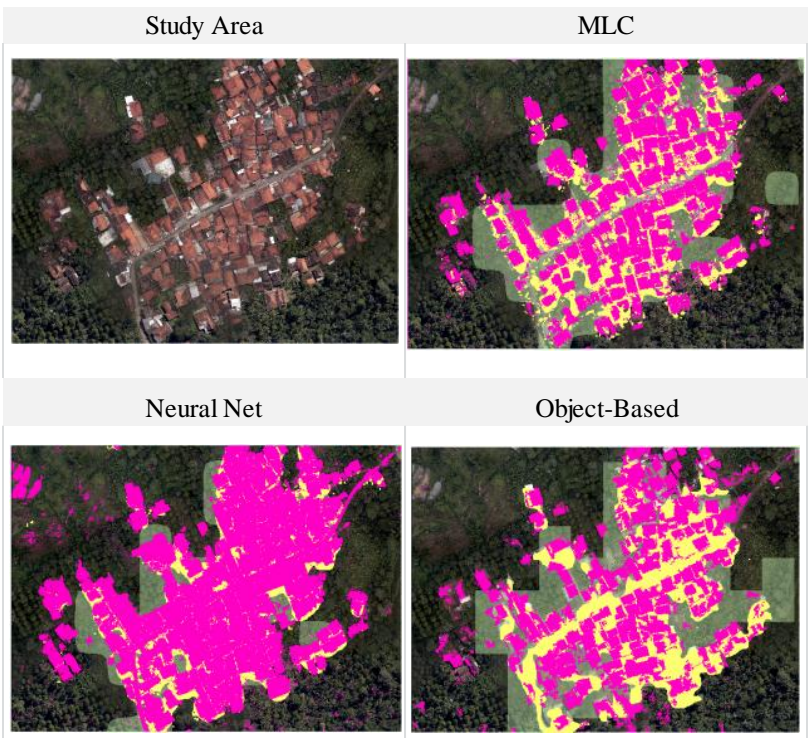

Figure 6. Pattern consistency for settlement feature that retrieved from several data with several digital classification methods

Pictures above represent that object-based classification more suitable applied for data with high spatial resolution and not satisfying for data with medium spatial resolution such as Landsat 8. Nevertheless, the setting parameter in this 
classification method still needs to improve. Neural net classifier gives more consistent shape than others, then the maximum likelihood classifiers (MLC) takes less consistency, there are many feature seen in one data, but doesn't seen in others data.

\section{CONCLUSSION}

The research proved that digital classification statistically gives satisfaction and provide computing solutions to the limitations of visual classification methods. However, if the classification result compared with other data that generated from visual interpretation, the accuracy assessment doesn't signify satisfaction value. That matter can caused by many factors i.e. interpreter knowledge, vision and subjectivity; moreover can caused by the band combination used in classification and also classification scheme that implemented.

Object-based classification method gives the best result than others classifiers. Object characteristic approach in segmentation and classification method can deliver best kappa value followed by Neural Net Classifiers and then Maximum Likelihood Classifiers (MLC). From this research, the objectbased classification more suitable applied for data with high spatial resolution and not satisfying for data with medium spatial resolution such as Landsat 8.

This study wants to know, how far digital classification can deliver pattern consistency of land cover information for certain level of map scale. Pattern consistency that generated from digital classification not yet delivers a satisfaction result. In this research Neural Net classifier gives more consistent shape than others. For further study, the using of band combination needs to be modified, for example the using of NIR band for SPOT and Aerial Photo data. Then, the improvement in pattern consistency computation, therefore the examination can presented quantitatively.

\section{ACKNOLEDGEMENTS}

Data and information was used in this research provided by Geospatial Information Agency in Indonesia. Thanks for Aji, Ratna and Aldino for online discussion for part of this research. And also thanks for Mrs Nurrohmad Widjadjanti as our supervisor in Geomatic Master's Degree Programme, Department of Geodetic Engineering, Faculty Engineering, Gadjah Mada University.

\section{REFERENCES}

Aguirre-Gutiérrez, J., Seijmonsbergen, A.C., Duivenvoorden, J.F., 2012. Optimizing land cover classification accuracy for change detection, a combined pixel-based and object-based approach in a mountainous area in Mexico. Applied Geography 34, 29-37.

Al-Doski, J., Mansor, S.B., Shafri, H.Z.M., 2013. Image Classification in Remote Sensing. Journal of Environment and Earth Science Vol. 3, No.10, 2013.

Avci, Z.U., Karaman, M., Ozelkan, E., Papila, I., 2011. A Comparison Of Pixel-Based And Object-Based Classification Methods, A Case Study: Istanbul, Turkey.
Blaschke, T., 2010. Object based image analysis for remote sensing. ISPRS Journal of photogrammetry and remote sensing $65,2-16$.

Bruce, D., 2008. Object oriented classification: case studies using different image types with different spatial resolutions. International Society for Photogrammetry and Remote Sensing.

Gholoobi, M., Tayyebib, A., Taleyi, M., Tayyebi, A., 2010. Comparing pixel based and object based approaches in land use classification in mountainous areas, Proceeding of the ISPRS Commission VIII Mid-Term Symposium "Networking the World with Remote Sensing", Kyoto, Japan, pp. 9-12.

Ghosh, A., Joshi, P., 2014. A comparison of selected classification algorithms for mapping bamboo patches in lower Gangetic plains using very high resolution WorldView 2 imagery. International Journal of Applied Earth Observation and Geoinformation 26, 298-311.

Jonsson, L., 2015. Evaluation of pixel based and object based classification methods for land cover mapping with high spatial resolution satellite imagery, in the Amazonas, Brazil. Student thesis series INES.

Lillesand, T., Kiefer, R.W., Chipman, J., 2004. Remote sensing and image interpretation, Fifth ed. John Wiley \& Sons.

Mather, P.M., 2004. Computer Processing of Remotely Sensing Third ed. John Wiley and Son, England.

Nasional, B.S., 2010a. Spesifikasi penyajian peta rupa bumi Bagian 2 Skala 1:25.000. BSN, Indonesia.

Nasional, B.S., 2010b. Spesifikasi penyajian peta rupa bumi Bagian 3 Skala 1:50.000. BSN, Indonesia.

Oruc, M., Marangoz, A., Buyuksalih, G., 2004. Comparison of pixel-based and object-oriented classification approaches using Landsat-7 ETM spectral bands, Proceedings of XX ISPRS Congress, p. 5.

Pontius, R.G., 2000. Quantification error versus location error in comparison of categorical maps. Photogrammetric Engineering and remote sensing 66, 1011-1016.

Qian, J., Zhou, Q., Hou, Q., 2007. Comparison of pixel-based and object-oriented classification methods for extracting builtup areas in arid zone, ISPRS Workshop on Updating Geospatial Databases with Imagery \& The 5th ISPRS Workshop on DMGISs, pp. 163-171.

Qian, Y., Zhou, W., Yan, J., Li, W., Han, L., 2014. Comparing machine learning classifiers for object-based land cover classification using very high resolution imagery. Remote Sensing 7, 153-168.

Richards, J.A., Xiuping, J., 2006. Remote sensing digital image analysis. Springer.

Shao, Y., Lunetta, R.S., 2012. Comparison of support vector machine, neural network, and CART algorithms for the landcover classification using limited training data points. ISPRS Journal of photogrammetry and remote sensing 70, 78-87. 
Stehman, S.V., Czaplewski, R.L., 1998. Design and analysis for thematic map accuracy assessment: fundamental principles. Remote Sensing of Environment 64, 331-344.

Story, M., Congalton, R.G., 1986. Accuracy assessment: a user's perspective. Photogrammetric Engineering and remote sensing 52, 397-399.

Weih, R.C., Riggan, N.D., 2010. Object-based classification vs. pixel-based classification: comparative importance of multiresolution imagery. The International Archives of the Photogrammetry, Remote Sensing and Spatial Information Sciences 38, C7.

Xiaoxia, S., Jixian, Z., Zhengjun, L., 2005. A comparison of object-oriented and pixel-based classification approachs using quickbird imagery. 